\title{
Universal Nominations Samples in Main Languages
}

\author{
Kulzhanova Bakytgul \\ Ph.D., the Associate Professor. \\ Kazakh national University after Al-Faraby, \\ Faculty of Philology, Literature andWorld languages \\ Kafedra KazakhLinguistics \\ Cumhriyet elite of Kazakhstan Ministry of Science \\ « Successful teachers of » European Scientific Industrial Palataki \\ the "Golden medalyo ", and "Quality diplomacy » owner
}

\section{Sagyndykuly Berikbay}

Dr. professor

Kazakh National University after Al-Faraby, Faculty of Philology, Literature andWorld languages Kafedra KazakhLinguistics, Kazahkstan, Almaty

Abstract

Significant discoveries are made in Turkology in recent years. As a result, there is a great opportunity to explore in-depth of the history of the word. If to be exact, the most important things, the archetypes of consonant of Turkic languages (including world languages in its broad sense) are identified. Significant results are made due to the fact of clarification of original and archaic types of sounds. The importance of the restoration of archetype of consonants and vowels in retrospective direction or, on the contrary, the replacement of their synchronic variants that were formulated over time in perspective direction is the following: if etymology of any word is analyzed, it will be easier to explore its origin.

Keywords: universal, nomination, samples, main, languages

\section{Introduction}

Among many examples, sol' (salt) (a white crystal substancewith apungent taste that is used as a flavoringfor food)in the Russian language is an equivalent of tyz (salt) (a white crystal substanceused to add a savory and spicy flavor to dishes)in the Kazakh language. However, there is another doublet for this word Lexical meanings are the following - 1) a salt swamp where feet are sunk into: 2) geogr.a desert and semi-desert where there is an easily soluble salt in upper layer, and sometimes it is a soil of steppe and forest-steppe zone;3) a white mark of salt solution. In addition, we can notice that sor is used in its broad sense in ancient times in the Turkic languages (including the Kazakh language). If to compare this word with the Russian language equivalent "sol'" (соль), there is only one difference in $\mathbf{r} \mathbf{I}$ phonemes. Sonorant sound I is formulated from sonorant sound $\mathbf{r}$ in their course of historical development. In other words, the original and archaic type of $\mathrm{I}$ is- $\mathrm{r}$. Its indigenous form -sor will be formed. Russians used it in ancient times due to the regulations of the language. Therefore, sor -is a common word for both Turkic and Slavic people from ancient times.

The words shatu (шату) in the ancient monuments was used in the meaning of "ladder". It's an incomprehensible archaism at present time. In the Kazakh language saty (саты) means: 1) a ladder that is used to enter the house or to go up or down stairs;2) a portable framework of wood in the form of two long parallel members connected by several parallel rungs or steps for climbing up the roof of the house or barn.It is very difficult to find out that words shatu (шату) and saty (саты) are rooted word without the appeal to professionals. The difference is in the matching of $\mathbf{s h}(\mathbf{w}) \sim \mathbf{s}$ (c)andu (y) $\sim \mathbf{y}$ (ы). Sh (w) and $\mathbf{s}(\mathbf{c})$ are dialectic signs of Oguz and Kypchak languages. Rounded vowel $\mathbf{u}(\mathbf{y})$ in the Oguz languages is always changed into the unrounded vowel y (ы) in the second and third syllables in the Kypchak languages: azuq> azyk, aguz> auyz, qabuq> qavyq, and etc. Vowel $\mathbf{u}(\mathbf{y})$ remained as an archetype in the Ogyz languages, whereas in the Kipchak 
languages it was reduced. Considering the fact that the sound $\mathbf{Y}(\mathbf{b})$ was originated from $\mathbf{U}(\mathbf{Y})$, there will be no doubt that these two words were originated from the same word. It can be shown like that: shaty (யamy) saty (camb) < satu (camy). The above-mentioned examples show the importance of original, ancient and archaic types of sounds when dealing with etymological researches.

As a result of in-depth study of the linguistic economy the restoration of the original form of extinct sounds, syllables with the help of original type, ancient type and archaic type is very essential in the course of the historical development. For example, variants that are common in the literary language: balbıra albyra, badyraq adyraq, baqyray adyray, bedireyбалбыра албыра, бадырақ адырақ, бақырай адырай, бедірей едірей) show that sonat b was sometimes remained, sometimes lost at the beginning of these words. But the ancient form $-\mathbf{b}$ is not $\mathbf{a}$ form of sound reduction; it's easy to restore the reduced form because of being of the same variant. Moreover, we can notice that sound din variants dokigen onkigen, dabyra abdyra, delben-delben elben-elben (дөңкиген өңкиген, дабыра абдыра, делбеңделбең елбең-елбең) and sounds $\mathbf{t}, \mathbf{s}$ in variants tarbi arbi, sarqıra arqıra (тарби арби, сарқыра арқыра) were reduced [2, 87-130 pp.].

This phenomenon is observed in the comparison of the historical manuscripts with the modern Kazakh language. For example, asyrga - syrga (асырға-сырға) in the manuscript "Khusrau ua Shirin". La'aldın qosh asyrgalar qulaqda (Ла'алдын қошасырғаларқулақда) - double earrings made from ruby stone. In the Kazakh language syrga (earrings) means fashion jewelry for women's ears made from various precious metals and stones (gold, silver, diamonds, sapphires, rubies and etc.). Here the sound $\mathbf{a}$ is reduced at the beginning of the word. But it remained its lexical meaning. In the ancient Turkic dictionary artut(apmym) is a gift, offering: artut alyp anungyl (артут алып анунғыл) - tartu (тарту) or to present. In the Kazakh language tartu (mapmy) means to present a special gift and valuable present for someone. In the language of historical monuments the word artut (артут) is the contemporary archaism, which is completely understandable. The omission of consonant $t$ and its gradual disappearance made it archaic word. The difference from tartu (тарту) is that it is presented in ancient form: tart+ut (mapm+ym). The plural meaning of this word in the Kazakh language is lost and that's why last sound $\mathbf{t}$ seems to be subject of elision.

We don't have a purpose to numerate findings founded in the article. We are trying to prove that the origins of world languages are the same with the help of previously unknown regulation and laws of different languages and with the help of a series of articles. There are similarities in terms of nouns, adjectives, numerals, verbs, pronouns and etc. First of all, we found it right to start from related nominations that are common for all languages of the world.

There is a proof of the existence of objective and historical basis of the same lexical database for all world languages. Information sent through representatives of God is becoming a reality one after another scientifically. It is also true that the world suffered from flood. According to legends come to us, all people at times of God Nukh (Noi) spoke in one language. There was no need of a rich vocabulary stock for a few people escaped in the ship. Everyday vocabulary was used then. Hence, the whole system of the ancient language was broken down. The narrow range of vocabulary used by the flood survivors was formulated as a foundation for all languages of the world in the course of historical development. According to our experience, there are thousands of archetyped roots.

PAPA (FATHER). According to the information in "Etymological dictionary of Turkic languages" by E.V. Sevortyan, the forms papa> baba, baba> aba> ebe, papa > apa (that stand for father) that mean the concept of parents are basically spread in all world languages (more frequently in one language and to a lesser extent in another one). There were no voiced consonants and close vowels according to the development evolution of language not only in Turkic languages, but also in all world languages in the ancient unknown period in the history. Voiced consonant and close vowels are gradually appeared in the dynamic development of voiceless consonants and open vowels [1. Thus, the variants papa> baba> aba> ebe are formed on the basis of the processes of voiced consonants, closed vowels and linguistic economy. The most correct list of these variants is papa and baba without taking into account their close and economized forms. The variant baba is formed as a result of changing voiceless consonant $\mathbf{p}$ into voiced consonant $\mathbf{b}$. Thus, the most ancient form and archetype of all variants is papa. According to scientist, forms papa and babaare spread in the Iranian, Semitic, Indian, African, Chinese, Caucasian and European languages in the meaning of "father", "grandfather", "grand grandfather" and etc.[1. 5-38 pp.]. For example, in the Russian language papa is a father (primary meaning), otez - a fatherin relation to theirchildren [4]. 
The first sounds were lost in the course of phonetic development in some languages: papa> apa, baba> aba. The reason for this is due to the shift of word stress. The first syllable was stressed in ancient times, then it was moved to the second syllable. In this case, the first sound does not play a discernable role. If word stress remains unchanged, papa and baba will be stable. All wisdom is here.

Both forms are spread in the "Ancient Turkic Dictionary" (ATD) and there is a difference in meaning between them: Aba I mother (ATD); aba II [tib. A- pha] father (ATD); aba III an ancestor; aba iazty ersay bayat qynaty- when ancestor transgressed, the God punished him; aba oglany - human, humanity: tortutti aba oglanyn bir bayat - single God created human being (ATD); apa I. elder relative, elder sister: apam olgen erkanta bitig berimiz - when my elder sister died, we gave (this) document; 2. a mother [6].

We can notice that apa, aba are used both for men and women, their meanings are not classified by the gender. However, it is common not only for the Turkic people, but for all nations in the world as well. The common viewpoint of Turkologist is the following: "Composition and relationship of meaning abaand others reflects the systemof consanguinitythat emergedin the early stagesof tribal relationsof the Turksuntil the formationof family andkinship relations, wherethe concept of "father""mother"and their offspring are central notions, whereas in the term apa, these meaningsdon't bear activeuse [3. 56p.] In spite of not being classified into a gender groups, the above-mentioned nominations of the most ancient times were soon gradually changed, each form took a certain lexical meaning or there was a little semantic difference. According to linguistic facts, Turkic people used papa as apa as a result of omission of the first sound. These changes weakened the seme on gender, and gradually it was lost. Finally, apa is used for only female gender. The voiced variant of apa is aba, and on the contrary, it was more common to man and it became stable in some languages. For example, aba> abu means "father" in the Arabic languages. Noun apa in the Kazakh language is a seme which is used for woman.

Apa. 1. A mother of a child. 2. A sister who is elder than others'. The first meaning of these definitions given in the explanatory dictionary of the Kazakh language -a mother of a child - is peculiar to dialectical feature rather than to national specifics. And the lexical meaning of "a sister who is elder than others'" is common for all Kazakh nation. This word has variants in the spoken language such as apeke(әпеке), apke (әпке). It is clear that apke (әпке) is derived from apeke (әпеке). And pair ekemay be the origin of the word ekech (small) from the medieval manuscript. Then it stands for "a little sister" (kishi apa). The last consonants ch sh seems to be extinct. Their way of development : apa ekech> apekech> apeke> apke (апа екеч>әпекеч>әпеке>әпке).

Apa is a word used to call a woman who is older in the Kazakh language. It means "a mother in law", "stepmother", "brother's wife" in other Turkic languages and besides it stands for "a woman" in general. Of course, all derived meaning appeared later.

Therefore, we consider wide-spread papa as a original form of apa, which is Turkic variant. In other words, it is just one step of this chain papa> baba, papa> apa> appa, baba> aba> ebe. Some Turkologists assume that the archetype of apa (апа)can be appa (аппа) [3. 54p.]. We cannot agree with it. The sounds interpreted together in some languages because of some reasons are the rule of law. For example, famous figure of Islam, an outstanding person Kosha Akhmed Jasaui (Йаcayn) can be said as Jassaui (Йассауи) in the spoken language. Achy (ачы - bitter) gradually became ashy>ashshy>ashy (ашы>ашшы>ащы) in the ancient Turkic languages.Secondly, appa (anпa) occurs in certain regions and in certain languages (in Balkar languages, Turkic and Tatar dialects) and it is not Turkic phenomenon at all. On the contrary, appa(anna) is formulated from the ancient form apa (апа):apa (апа)> appa (апna). It can be pronounced as aqa (aga)>aqqa, ana>anne (ақа (аға)>аққа, ана>анне) in the Turkic languages.

Over time, semantics of not only the form of papa, but also baba is classified. For example, baba which meant both father and mother took a meaning of "father's father" and "mother's father" in the Iranian and Turkic languages, whereas in the Russian language it was used in the meaning of "old woman" reflected in the language in the form of baba, babushka (grandmother). In short, historical, social, cultural and political circumstances lead to the change in a wide range of meanings. The most ancient form papa is still present in the Indo-European languages, but this form has been changed slightly in terms of phonetics in different system of languages. According to facts, some languages kept the seme related to male gender, whereas other languages developed the seme of female gender.

Thus, the issue on genetic basis of all languages of the world is appeared. However, scientists doubt about genetic relationship and common basis of all languages. Applying to various excuses, they don't want to recognize that all 
languages are formed from one archetype For example, they believe that the similarities of all languages are formed by speech babblings of infants that doesn't bear any meaning: "Theoretical difficulties associated with terms of kinship, are generally clear. They lie in the fact that the commonality of basic terms of kinship (as well as some other lexical or lexicalgrammatical categories) in different language families (Indo-European, Altaic, Finno-Ugric and others) needs to be explained, in which we must obviously exclude genetic commonality of all these lexical categories. Otherwise, there is a question about the genetic relationship between the language families itself. The hypothesis of the origin of babbling of terms of kinship is designed to resolve this conflict "[3. 57p.].

We cannot agree with the hypothesis that related nominations are formed from the infant's speech babbling. Repetition of one syllable twice in words such as pa +pa, ba + ba, she+she, ma + ma can't prove this hypothesis. In our view, these repetitions are used for the purpose to "call" and "draw attention". They are just addressing words of children for parents. If so, the basis for the emergence of such nominations bears some reason (motive). However, this motive is forgotten because many thousands of years passed.

The existence of special phenomenon in linguistics is observed as a result of long years of study, which wasn't under the attention of linguists for many years. The basic lexis of any language is formed with the help of lexeme containing only one consonant and one vowel. Language unit which contains only the combination of one consonant and one vowel and which holds either lexical or grammatical meaning; which is unknown in history and formed from the ancient times is called archeseme (tubirtek) by us. Archeseme is language unit like a phoneme, morpheme, word, phrase and sentence. Forgotten motives can be restored owing to the theory of archeseme.

Papa, baba - are not babble of infants, they are independent words used by adults. Parents taught their children these words, especially the archetype pa, ba in the meaning of a head and leader of the family. Let's try to find out the etymology of these archetypes.

The nomination shamba in the Sanskrit (Persian) language contained two parts in the ancient times. Sham means "day", ba means "main", "first". Then, the whole word refers to "the main day". According to religious faith, the first day of the week is the date of the movement of the whole world. The Kazakh proverb "Saturday is good luck" originates from this. The syllable ba is also used in the same meaning in words such as baash, bash, bas in the Turkic languages. At the beginning it seemed that long pronounced vowel a in paarbaa was used to call men, whereas short-pronounced vowel a in pa $\sim$ ba was used to call woman. If children wanted to call both father and mother, they just said paapa $\sim$ baaba. That's why there were no gender differences referring to these words. There is also part va in the Russian word golova (bas - head). Consequently, words papa, baba are used to call members of family. The lexeme papa that is used to call parents was developed in three directions in terms of phonetics.1) Remaining the original form: *papa>papa. 2) Being voiced, economized and closed: * papa> baba>aba > ebe. 3) Omission of the first sound in spite of being closed: *papa> apa> appa. In spite of changes in terms of phono-semantic sense, the word papa haven's lost its gold core of being the most common word for all world languages.

ANA (NANA- MOTHER).In the Kazakh language.1. a mother.2. A mother in general 3. Basis, main, root. This word is spread in all Turkic language in its different forms ana ene ine anna, etc. Moreover, ene is used inTungus-Manchzhur language, eme is in the Mongolian.Nana is used in the Indo-European languages. That is one of the most common words in the world. There are a number of primary and figurative meanings in the Turkic languages. 1) The meaning of "mother" is widely used in all Turkic languages. 2) It refers to "a mother of father" - "grandmother" in Turkish, Turkmen, KarashaiBalkar, Tatar, Uzbek dialects. 3) It is used in the meaning of "respected mother" in a number of languages. 4) It is used as a "female animal" in some Turkic languages. 5) In the Tyva language it stands for "teacher". 6) Sisters are called with this nominations in the Tuva language and in dialects of the Turkmen language. 7) Kazakhs call mother of his wife as "ene".

Turkologists are attempting to discover the origin of this word. G.Vamberi associates it with the verb em which means to "suck", "nurse". G.Ramstedt compared all forms in the Tungus-Manchzhur, Mongolian, Korean languages and recognized the common basis for all languages. M.Ryasyanen looked for the origin of the nominationana in the Ural-Altai languages. These languages consist the Finnish, Hungarian languages. G.Derfer believes that this word appeared as a result of child's babbling, and he compared all similar parallels in the Indo-European languages [3. 278-281pp.].

In this case, we would like to propose a new version of etymology of ana which will explore its origin fully. If we compare interaction of sonorants $\mathbf{m}, \mathbf{n}, \mathbf{n g}(\mathbf{M}, \mathbf{H}, \mathbf{H})$ we can notice that $\mathbf{n}(\mathbf{H})$ was the first sonorant, $\mathbf{m}(\mathbf{M})$ andng( $\mathbf{H})$ were the latter 
phonemes.There are enough language facts that can prove it. For example, in the ancient Turkic language - unytmak (унутмақ - to forget) - in the Kazakh language umytpaq (ұмытпақ); in ancient Turkic language * tonguz (тоңуз) in theTurkish language domuz (домуз); in the ancient Turkic language * sunguk (сүңүк)- in the Turkish, Azerbayzhan, Chagatai languages sumuk (сүмүк); in the ancient Turkic language * konglak (көңләк - dress) - in the Turkish language gomlak (гөмләк); in the Tatar dialects agyn (ағын)- in theKazakh language agym (ағым); in the Kazakh language menin (менің -my) - in the Tatar language minim (миним); in the Kazakh language Zhanpeyis> Zhampeyis (Жанпейіс>Жампейіс), Qurmanbek> Qurmambek (Құрманбек>Құрмамбек), endi emdï (енди емди - now) and so on. One of the prominent linguists L.Levickaya and specialist of Altay studies M.Ryasyanen recognize $\mathbf{n}(\mathbf{H})$ as a first phoneme rather than $\mathbf{m}(\mathbf{M})$ [2.68-69 pp.].

Linking word na (на) in the Russian language is used in the meanings of"here you are" and "to take". Interjection ma (мә) in the Kazakh language is also used in the meaning "to take" in the form of gesture. Similarities in lexical meaning and form of both words prove that these words were of the same origin once upon a time. That word may have been used as a basis for nominations na+na (аna) (на+на (ана)), and mama (мама) in the Indo-European languages. In other words, mother gives a suck to her child with words na, na (ma, ma) (на, на (мә, мә)).And consequently, baby understood the word na as "breast".

Mama (мама)in theKazakh language is considered as a word borrowed from the Russian language. It means - a mother.But there is also one more meaning of mama in the Kazakh language which refers to "a part of a body of a woman to produce milk and a breast of a woman to feed a child". There is also a section on "How Adam argued with mother of Haya and how they get reconciled" in the work called "Kissa-ul anbiya"by Rabguzi in the XIVth century. This fact proves that mama is spread not only in Indo-European languages, but in the Turkic languages as well.We can rely on the fact that $\mathbf{m}$ was formed from $\mathbf{n}$ and we can restore any word with the help of interchange of $\mathbf{m}$ into $\mathbf{n}$.If we reconstruct the original form of mama, it is easy to come to the form nana.The form nana is the same as in the Indo-European languages. It is obvious that in the course of historical development the lexeme nana gradually became mama. A great maternal function of a mother for her children - is teaching and upbringing. But Russians entrust this function to nyanya (nurse), and generally speaking nyanya came from the word nana: nana> nyanya (нана>няня). The first two letters of the word mat' (мать) in the Russian language which means "mother" is harmonious with the lexeme mama. Overall, all these words remind a mother of a child. Thus, the archetype of all analyzed words is nana. The table of their phonetic development can be shown in the following way:

\section{1. *Nana> mama> ama> eme (Нана>мама>ама>еме) \\ 2. *Nana> ana> anna> ene> enne (Нана>ана>анна>ене>енне)}

We can notice the following changes if we pay attention to the table nana> mama> ama> eme: 1) mama (мама) is formed as a result of the change of $\mathbf{n}(\mathbf{H})$ into $\mathbf{m}$ (м) in the word nana (нана); 2) ama (ама)is found due to the omission of the first letter of mama (мама). But despite of the omission of the first letter, it hasn't lost its lexical meaning; 3) Open vowels became close vowels in some languages, and consequently eme (еме) is formed. This form is used in the meaning of "mother" in some Turkic languages.

We can notice the following changes if we pay attention to the table consisting the following parallels *nana> ana> anna> ene> enne ("нана>ана>анна>ене>енне): 1) ana(ана) is formed as a result of the linguistic economy which lead to the disappearance of the sonorant $\mathbf{n}(\mathbf{H})$ in the word nana (нана); 2) anna is formulated to show the high emotion, emotive state of a person.It close form isenne ; 3 ) ene is process of changing open vowel into close vowels. The first parallels are peculiar to the Indo-European, Tungus-Manchzhur and Mongolian languages, and latter parallels are characteristics of the Turkic languages. In short, in spite of various changes of this form *nana $\sim$ mama $\sim$ ama $\sim$ eme $\sim$ ana $\sim$ anna $\sim$ enne ene ine (нана мама ама еме ана анна енне ене ине), it hasn't lost common similarities and interrelation and it kept the fact that it is the universal lexeme for all languages of the world.

ATA (TATA). This word in the Kazakh language is used in the following meanings. 1. a father. 2. a big father, and a father of a father, grandfather. 3. a tribe or group of people who are relatives by their blood; 4.a gender, race, place of origin and 
a breed. 5. a father-in-law of spouses. 6. The elder, the old man(in the sense of respect). 7. in a firgurative meaningit refers to the basis of something or the beginning of something.

The word was used in the meaning of "father" in the monuments (XI.) "Qutadgu Bilig": if your father died, I will be your father [6. 65 p.]. It was also used in the same meaning in the XIVth century monuments: die like his father [7. 41 p.]. According to this, meanings such as "a father of a father", "a father-in-law of spouses", "origin", "breed" appeared gradually over time in the Kazakh language.

Ata is almost present in all Turkic languages. In the Chuvash, Azerbayzhan, Tatar languages and in the Turkmen dialects it means "father"; in the Turkic, Turkmen, Karaiym, Kyrgyz, Karakalpak, Uighur, Altai, etc. languages it stands for "a father of a father", "ancestors"; in the Turkic dialects and monuments it refers to "a brother or a sister". This word has also the meaning of "man" in the Nogai, Tatar, Bashkir languages [3. 200-201pp.].

There are a few phonetic variants of ata: a:ta, ata, ada, ede, ati,adi. However, we can notice the processes of changing of sounds into voiced consonants and close vowels. Some researchers believe that this term among other words that mean kinship relationship may occur later in time. According to authors of the dictionary of "Etymology of Turkic languages", atta (arra) means "a father", "ancestor" in the Latin, German, Albanian languages. It is used in the same sense in the Hittite, Hurrit and Elam languages. These facts identify that this word appeared immediately after the words papa, baba, nana, mama.

Children born one after another without any gap is called tete (тете) in the Kazakh language. This word is pronounced as tata (тата) in Ural region which is an open variant of vowels. Both tete (тете) and tata (тата) are formed as a result of repetition of the first syllable twice like in words such as ba+ba, pa+pa, na+na, ma+ma, she+she. Almost all words which showed kinship relations in the unknown ancient times kept these regulations. The shift of the word stress from the first syllable into latter ones lead to the omission of the first letter.Tata also lost the first letter, and then used as ata (ата) in the Turkic languages. Initially, children called age mates' (tete (tata)) of his father as ata, then gradually it may be used in the meaning of a"father". Changes in meaning are regulated by relationship among people and internal and external factors. In modern literary language tate symbolizes a sister who is elder than others'. There is no doubt that tete, tata, tate (meme, mama, mame)are similar roots in terms of phonetics. There is only a change in vowels.

Tetya (тетя - aunt) (a sister of father or mother and uncle's wife), dyadya (дядя- uncle) (a brother of father or mother, and aunt's husband) in theRussian language are initially used to call age mates of parent like a term tata (тата). Thus, we can come to conclusion that the lexeme ata moved aside the lexeme papa in spite of the appearance later than papa. Variants derived from papa such as aba ebe (papa>apa>aba>ebe) (аба ебе (nana>ana>аба>ебе)) in the Mongolian, Tungys-Manchzhur languagesare used more frequently than ata (ата).

Dada (дада)is formed as a result of the process of changing voiceless consonants of tata (тата) into voiced ones. The variant is spread in the Turkish, Azerbayzhan, Uighur, Uzbek languages. Basically, it means "a father", "a father of father". The origin hasn't been discovered by Turkologists yet [3. 212-213 pp.]. Dada (дада)stands for"a father of father" in the Persian language [5]. In the Russian language it is ded (дед)which is closed variant (a father of father or mother) [4]. The Persian language and Russian language belong to the family of Indo-European languages. Some words are universal for many languages, but why aren't they considered to be the common words for all world languages? Because majority of scientists understand various versions of this variant tata, ata, atta, tate, tete, tetya, dyaydya, ded, dada (mama, ama, amma, mәте, тете, тётя, дядя, дед, дада) as separate words. They don't take into account their phono-morphosemantic way of development. Phonetic, morphological and semantic derivations must always be taken into consideration.

The most ancient (archetype) form of the above-mentioned variant - if we don't take into account voiced, economized, closed forms, - is * tata (тата). It is formed with the help of repetition of archesyllable ta (та) twice.The form ta (та) is a universal numeral for all languages in the world. It means one, single. .

The lexical meaning of this form can be determined on the basis of materials of the Russian, Persian, Turkic languages without any doubt. Ta (та) is a root for both "ta +q" («та+қ») ) that means "single, only" and "ta+l" («та+л») that stands for "one item or piece of the similar type". This dead root was founded as the foundation for lexemes"ta+ram", "ta+ rmaq", "ta+rau", "ta+ra" («та+рам», «та+рмақ», «та+рау», «та+ра»). All these words means "privatization, personalization". It also proves that the form taq (тақ) is not pure Iranian word, it's Turkic word. 
The above-mentioned facts clearly demonstrate that there is a regularity of the change of open root into closed root in the course of historical development. According to this regulations, zhek (жек) is a closed variant of taq (тақ). Thus, the following matching is formed:t zh, a e, q k (т ж, a e, қ к). But zhek (жек) is not used alone; it is a part of the double word zhekpe-zhek (жекпе-жек)(a fight of two people with each other). The dead suffix $\mathbf{e}$ in the ancient form was added and so the word zheke (жеке) (only, single) was appeared. This fact proves that one-syllable word taq (тақ) is not pure Iranian word; it is rather common for all world languages.Let's pay attention to the fact on typological point of view. The meaning of "one, the only, the unique" is given by the word od+in (од+ин - pronounced as ad+in) in the Russian language. Here consonant $\mathbf{d}$ is a variant of voiceless $\mathbf{t}$. Ad ta (ад та) are variants of vowel harmony. Vowels may be placed both after and before consonants according to regulations of internal flection. Therefore, both ad (ад) and ta (та) means "one".

The element ta(тa) with the meaning "one" is spread in other words of our language. Let's pay attention to the etymology of the adjective tap-tuynaktay (тап-тұйнақтай -clean, accurate). The word tuynaq (туйнақ - hoof) is found in the XIVth century monument "Khusrau ua Shirin": Temir teg tuynaqy taglar qazar ol (Темир тег туйнақы тағларқазарол - iron hoof digs the land) [7. 211 p.]. Tuynaq (туйнақ))in the monument and tuyak (тұйақ) in the Kazakh language are the same. Only the letter $\mathbf{n}(\mathbf{H})$ was lost because of the linguistic economy. All animals in zoology are divided into odd hoofed animals and pair hoofed animals. Thus, tak+q $(\mathbf{\tau a}+\mathbf{k})$ and $\mathbf{t a}+\mathbf{p}(\mathbf{\tau a}+\boldsymbol{n})$ are rooted words. Latter letters $\mathbf{q}(\mathbf{k})$ and $\mathbf{p}(\boldsymbol{n})-$ are epithesis sounds that are added to the end of one syllable words. Privilege of accuracy of odd hoofed animals over pair hoofed animals was taken into consideration, and thus the word was used in its figurative meaning from the ancient times. The primary meaning of it was completely forgotten.

Now let's pay attention to the etymology of the word tay (тай). Тау (тай) - a one year old foal of horse. One year has passed and foal became tay. I'm overwhelmed by riding a tay (Бір жыл өттіарадақұлыншағымтай болды. Тайғамініпбарамдеп, Көңілімдежайболды) (Talgarov. Tory taymyz). Here, the root ta (та)in the word ta+y (та+й) means "one", $\mathbf{y}(\breve{\mathbf{n}})$ is epithesis sound.If one pair of socks is lost, the Karakalpaks say "tay of one socks is lost" which is in the spoken language (it's taken from the talk of students').So there is no doubt that ta (та) means "one, the only, single" due to the above-mentioned facts.

The form ta of the locative case always indicates the meaning of "one". For example, Asan is at school (mektep+te). This combination clarifies that Asan and school are in one place. Watch is in the chest (sandyk+ta). Watch and chest are in the same place, we can find them in one place. The more sentences we analyze, the more sure we become that grammatical meaning of the locative case is "one".

Conclusion: ta (та) is numeral that is used in the lexical meaning "one" in the Turkic languages (as well as in all languages of the world). In the course of historical development it gradually became more and more abstract and became the language element which means permanent place and location. Consequently, we start to identify it as the suffix of the locative case. As linking words ta, te, da, de (та, те, да, де) show any object separately and individually (both Asan and Usen - Asan da, Usen de), we consider that they are similar to the suffixes of the accusative case.

Now, let's again pay attention to parallels that are common for all languages of the world

tata ata atta tate tete tetya dedya ded dada (тата ата атта тәте тете тетя дядя дед дада).

The archetype of these variants is a form of tata (тата). As ta (та) was used in the meaning of "one" in the ancient times, tata (тата) is transferred into the Kazakh language as " birbir" (бірбір - oneone). There are several brothers from one parents. Tata (тата) is a relative, who doesn't have any children, who is one of the closest person to you among them. As it was used differently in different parts of the world throughout the history, the scope of their use was widened. The numeral ta (та) that means "one" in theancient times has been changed completely in terms of phone-semantic way. Therefore, all nominations of a common relations for all the languages of the world have motive.

We are going to discuss such nouns askun (sun), ot (fire), zhol (road), numerals such as eki (two), bes (five), on (ten) as well as adjectives such as ak (white), sary (yellow), kyzyl (red), and pronouns like men (l), sen (you) that are universal for all languages in the next articles. 


\section{References:}

[1] Drevnetuyrskii slovar’. Leningrad, izd. «Nauka», 1969.

[2] Ibatov A. «Kutbtyng«Khusrau ua Shirin» poemasynyn sozdigi». Almaty, «Gylym» baspasy, 1974.

[3] Ozhegov S.I.Slovar' russkogo yazyka. Moskva,«Russkii yazyk», 1984.

[4] Persidsko-russkii slovar'. Moskva, izd. «Sovetskaya enziklopediya», 1970.

[5] Sagyndykuly B. Kazak tili leksikasy damuynyn etimologiyalyk negizderi. Almaty, «Kazak universiteti» baspasy, 2005.

[6] Sagyndykuly B. Kazak tilinin tarihy. Almaty, «Kazak universiteti» baspasy, 2011.

[7] Sevortyan E.V. Etimologicheskii slovar' tuyrskih yazykov. Tom I. Moskva, izd. «HNauka», 1974; tom II. Moskva, izd. «Nauka», 1980. 